\section{"CASES OF CONTRACTED TENDONS."} To the Editors of THE LANCET.

SiRg,--In The LanceT of April 22nd Mr. W. J. Tiry Gas recorded some cases of contracted tendons of the toes which he had treated very successfully by tenotomy of the extensor tendons and subsequent massage. The value of this contribution has been somewhat compromised by the use of the term "hammer-toes" as applied to these cases. This latter deformity consists originally in a flexion at the first phalangeal joint, which is produced, according to the observations of Mr. Shattock and Mr. William Adams, by a deficiency in the length of the lateral ligaments. In consequence of the downward projection of the second and third phalanges the toe is pushed up during progression till at length the extensor tendon acquires an "adapted shortening." "This implication of the extensor is secondary to the defect of the ligament. It would be useless to treat true hammer-toe by dividing - that is, by lengthening the extensor tendon. The flexion of the first phalangeal joint must first be corrected either by subcutaneous division of the lateral ligaments, as practised by Mr. Adams, or by resection of the articulation, as recommended in some cases by $\mathrm{Mr}$. Anderson. After division of the lateral ligaments the joint can generally be completely straightened without section of the extensor tendon, which is rarely necessary. In certain cases of talipes equinus, and sometimes without any such accompanying deformity, the extensor tendons are contracted. The appearance of the toes then much resembles that of hammer-toes. In both the toe is drawn upwards, but in the one case the first phalangeal joint is easily straightened and in the other that joint is fixed in a flexed position. It is probable that Mr. Tivy's remarks refer to cases of the first description, which can be successfully treated by tenotomy of the extensors but such an operation applied to hammer-toe would be fruitless and bring disappointment both to the surgeon and Bis patient.-I am, Sirs, yours faithfully,

Queen Anne-street, W., A pril 29th, 1893.

\section{J. MACREADY.}

\section{"POST-PARTUM HAMORRHAGE." To the Ealitors of THE LANCET.}

SIRS, - The clinical lecture in THE LANCET of April 22nd by Mr. Stanmore Bishop emphasises, according to more modern teaching and knowledge, the principle $I$ advosated some years ago in a paper entitled "Remarks on Postpartum Hæmorrhage." ${ }_{1}$ After evacuation of the uterus of all its contents and the use of a hot antiseptic uterevaginal douche, the next most valuable measure to adopt, both relatively and absolutely, in a case of post-partum hæmorrhage, I believe, with Mr. Stanmore Bishop, to be compression of the abdominal aorta. Its modus operandi he explains in terms almost equivalent to those employed by me in the paper referred to above. The methods described as in practice at Queen Charlotte's Lying-in Hospital in 1870 may be regarded as open to question in the present day; but I have no doubt that, though less scientific than those of modern procedure, they were of service in limiting the cases of post-partum hæmorrhage numerically as well as potentially, and I believe now, as then, would be of service in practice where it was found dificult to carry out more exact compression of the abdominal aorta by manual pressure. I am, Sirs, yours faithfully,

H. Cripps Lawrence.

Sussex.gardens, Hyde Park, W., May 1st, 1893.

\section{ISARCOMA OF THE BREAST: ITS DIFFEREN- TIATION FROM ACUTE CAROINOMA.}

\section{To the Editors of THE LANCEr.}

SiRS, - A clinical lecture on breast tumours published in THE LANCET of April 29th contains a proposition of so much practical as well as pathological importance that I will ask your permission at once to challenge the accuracy of the latter. The student is told that immunity of the axillary lymph ylands cannot be relied upon as a test of mammary sarcoma, Jifferentiating this from carcinoma, several cases in which those organs were found palpably eslarged being adduced in support. The error involved lies in a very common confusion of the more acute instances of carcinoma-development in the female breast with true sarcoma. The rapidly growing encephaloid carcinomata of this organ form soft, greyish, granular masses, which, under the microscope, consist of round or ovoid cells, never of spindle-shaped forms. If the margins are examined, the acinar arrangement characteristic of breast carcinoma will be found ; otherwise, the lesion will probably pass as " round-celled sarcoma." Little or no enlargement of the axillary lymph-glands can long be detected ; these structures, however, are actually infected and after excision of the breast growth therein is rapidly progressive. Per cortra, a sarcoma presents on section a yellowish quasi-gelatinous surface with distinct fibrillation, it is never granular; portions may be well organised, resembling a non-malignant fibroma. The microscope reveals spindle-shaped cells, ranged for the most part in bands, with, in the more acute examples, a variable admixture of roundish cells or free nuclei. No true sarcoma, arising from connective tissue cell-elements, ever fails to display fusiform cells in strands or bands, and no doubtful tumour should ever be designated by that title in the absence of this pathognomonic badge. The axillary glands are never infected - so, at least, said the late Dr. Samuel Gross ("Tumours of the Mammary Gland," p. 87), and for many years past I have vainly sought an instance to the contrary.

In surgical practice it is a matter of urgent necessity to aroid the confusion indicated, for, after the operative removal of a breast tumour (which, when incised, presents the grey granular-cut surface referred to), the surgeon who omits forthwith carefully to evacuate also the contents of the axillary cavity will fail gravely in his duty. Should he proceed to do this he will probably encounter some degree of enlargement previously undetected; in any case he will find evidence of deposits certain to have caused death, with abundant visceral deposits, within a few months. On the other hand, should the mass on section present the gelatinous fibrillated appearance indicative of true sarcoma, any interference with the axilla will only needlessly enhance the gravity of the operation.

I am, Sirs, your obedient servant,

HERBERT SNOW.

Gloucester-place, Portman-square, May 3rd, 1893.

\section{THE ETIOLOGY OF EMPYEMA OF THE ANTRUM. \\ To the Editors of THE LANCET.}

SIRs, - The question as to the part which teeth may take in the causation of the condition now usually denominated "empyema of the antrum "-a question cursorily alluded to by Dr. William Robertson in his valuable paper in Тнस LANCET of to-day-deserves discussion. The common association of polypus and other morbid conditions of the nasal cavities with empyema of the antrum cannot be denied; but it is a disputable point whether in a majority of such cases the mischief has had its prime origin in the nose or in the teeth and antrum. It is at least certain that in a large proportion of cases of simple empyema - and probably in by far the greater number-whilst no other cause is discoverable there exists in teeth in relation with the antrum disease sufficient to account for the symptoms and for the pathological changes in the mucous membrane of the cavity. It must, howerer, be pointed out that it is not quite exact to speak of dental caries as the cause of these effects; they are due rather to the sequelæ of caries-exposure and inflammation of the dental pulp and alveolar abscess. Septic matter in the root canals of teeth may find its way into the antrum; or inflammation with suppuration around the apices of roots may extend to the cavity. The former accident is the more common in carious teeth which have been filled, and in which, the cavity of decay being hermetically sealed, discharges can find vent only through the apical root-foramina. In many of there cas $\in \mathbf{S}$, particularly in those in which a chronic alveolar abscess finds free vent into the antrum, toothache does not exist, and, indeed, although $I$ and my colleague in practice in England have in late years tapfed the antrum in a large number of cases, in no instance bas a patient, suspecting his teeth, applied to us in the first instance. The diagnosis has always been previously made by surgical practitioners; but in a great number of instances a correct, diagnosis has not been made for months and eren ye?rs. These facts have been thoroughly illustrated 
in a series of cases seen in conjunction with Dr. Felix Semoncases which, I trust, he will some day publish. In these cases Dr. Semon hias diagnosed empyema and has eliminated every cause save a tooth. On extraction there has been invariably discovered septic infection arising from the tooth, and the cases have always been cured by assiduous antiseptic irrigation, although this in some long-standing cases has had to be persevered in for a protracted period. I am, Sirs, yours truly,

Wimpole-street, April 29th, 1893.

HeNRY SiwILI.

\section{"THE OPIUM QUESTION IN INDIA."}

\section{To the Editors of THE LANCET.}

SrRs, - I was much interested some time since in the discussion in THE LANCET on the opium question in India. In an experience of twelve years of medical practice in the Punjab I have had opportunities of observing the effects of the opium habit. It seems to me that a great deal more is made of the evil effects of it than is justified by the facts. Amongst the Sikhs, the finest race of men in this province, the habit is, I venture to say, well-nigh universal. Those who do not use the drug are, it might be said, exceptions to the rule. The Sikhs do not use tobacco, and hence perhaps the fact that they more than others indulge in opium, for men will have a stimulant or narcotic of some kind. It is a very common practice to give it, in the first place, to their infants to keep them from crying at night and disturbing the household. Every father knows only too well what it is to be roused at midnight to pace the floor with a crying child-i.e., if he is a generous busband and does not leave it all to the poor tired wife to do. All such troubles are, at least for the time, evaded by giving the little hopeful an infinitesimal dose of this prima donna, the queen of drugs. The future consequences, whatever they may be, do not concern the Sikbs, nor the rest either for the matter of that, for the practice is not confined to the race named. It is not a common failing with any of them to look ahead. That is left to qismat (fate), which will settle the future of the child to suit itself quite independently of any precautions on the part of its parents. As for adults, the habit generally begins with taking the drug, in the first instance, to alleviate some pain or to stop a cold or a cough (the whole race coughs). From two to thirty grains a day are taken. I have met with numerous instances of old men who have taken from twenty to thirty grains a day in two doses; but it is not conducive in any way whatever, as some imagine, to the commission of crime or to violence, or to maltreatment of wives or children, or any of the other little Christian pleasantries that are commonly indulged in by some of our countrymen who drink ardent spirits to excess. One never hears of crime being traced to the use of opium. The same is true of suicide. Opiumeaters here do not cut their throats or jump into wells or shoot themselves. I have been surprised to observe that most of those addicted to the habit, on the other hand, are strong and able-bodied and healthy men, living to the same age, so far as I know, as others. I have met with numerous instances of old men who have taken opium steadily for periods of thirty years and more and who are in every respect as active and industrious as others who have not used it. It must be added, however, that they are for the most part zemindars or farmers, who live an active out-of-door life, and who subsist very largely on milk. It is not pretended that the use of opium, notwithstanding the above statements, is harmless. Most of those I have met with have complained when questioned of feeling inconvenience from the habit, and $I$ have often been consulted about a cure for it, though rarely with success. It takes effort and courage on the part of the patient as well as medicine to break it off. I am, Sirs, yours truly,

$$
\text { F. J. NEWTON, }
$$

M.D Jefferson Med. Col., Philadelphia, U.S.A., Missionary Punjab, India. American Presbyterian Church, Ferozepore.

\section{NORTHERN COUNTIES NOTES.}

\section{(FroM OUR OWN CORRESPONDENT.)}

Infectious Disease in the North.

SMALL-Pox still lingers about the North of England. A case was reported last week in connexion with a travelling circus. At the late meeting of the sanitary authority at Stockton-
on-Tees the medical officer, Mr. Clegg, reported that in the past fortnight there had been eight cases of small-pox, six of which had arisen in the house from which a patient was removed on the 9th ult.; two of them had proved fatal. $\mathrm{Mr}$ Clegg, in his report on the health of Stockton-on-Tees during the past year, refers to the increase of phthisis during the year, which, he thinks, is to be attributed to the aftereffects of influenza. As regards scarlet fever, its spread, he is of opinion, is mainly caused by persons visiting infected houses, and in spite of all warnings neighbours will visit The weekly report of the medical officer of health of Leeds (Dr. Cameron) shows a further increase in the small-pox cases under treatment in the Infectious Diseases Hospital, the number on Saturday, April 29th, being 134 as compared with 111 for the week ended April 22nd. Of the 39 fresh cases reported, 38 were removed by the sanitary authorities. The total number of patients in the hospital on Saturday was 174, or an increase of 21 on the figures for the previous week.

Ambulance Work.

A meeting was held in the Town Hall, Alnwick, last week, at which the prizes \&c. were presented to the students. The chairman referred to the rapid development of ambulance work in the country. He believed the class started in 1888 under Dr. Scott Purves was the first in the North of England. Dr. Scott Purves, at the conclusion of the proceedings, received a presentation of a handsome gold pencil-case from the lady students. At Redcar, too, the railway ambulance class has received prizes and medallions. The class there has been instructed by Mr. McKinlay.

\section{Homicidal Insanity.}

A wave, so to speak, of homicidal insanity has been passing over the North of England lately. At Middlesbrough a lunatic shot a policeman, who was trying to secure him, through the heart ; and at Durham, last week, a lunatic shot at two bank clerks with a revolver and wounded themhappily, it is hoped, not dangerously - and then shot himself fatally. From some writing found upon the suicide it appears that he brooded over some supposed wrong, for he had an entry that "bank clerks and post-office clerks were all the same."

Small-pox Hospitals.

The City Council of Leeds have recently acquired the Manston Hall estate (100 acres in extent) and have erected thereon temporary wards for the accommodation of small pox cases. A scheme is being prepared which, if carried out, will result in the construction of a large hospital for infectious cases situated about three miles from the centre of the city.

The Out.patient Department of the Leeds Infirmary.

The much-discussed out-patient question has been under consideration at the Leeds Infirmary and investigations have been set on foot by the board of management, who have wisely determined to extend their inquiries over a lengthened. period before making any change in the present system.

Newcastle-on-Tyne, May 4th.

\section{IRELAND.}

\section{(From OUR OWN CoRrhispondents.)}

The late Professor Macnamara's Appointments.

Av election for a Member of Council of the Royal College of Surgeons took place on Tuesday last. There were four candidates for the Councillorship, Mr. Humphrey Broomfield being successful. One hundred and sixty-eight Fellows recorded their votes. Mr. Broomfield is assistant physician to Baggot-street Hospital, College Anatomist of the Schools of Surgery of the Royal College of Surgeons, and will prove an efficient member. On Thursday, the 4th inst., the Conncil will elect a representative of the College of Surgeons on the General Medical Council. There are fire candidates for the appointment. There are several candidates for the vacant post of surgeon to the Westmoreland Lock Hospital, but it is thought probable that Mr. M. A. Donnelly, F.R.C.S., resident surgeon, will be promoted. He has been connected with the institution for the past fourteen years.

\section{Richmond Lunatic Asylum.}

At a meeting this week of the Dublin Corporation a report was received from Sir Charles Cameron on the insanitary state 